\title{
ISOLATION AND IDENTIFICATION OF Acetobacter sp. FROM PINEAPPLE (Ananas comosus L.) AS NATA STARTER
}

\author{
Asmaul KHUSNA ${ }^{\star}$, Anis Usfah PRASTUJATI, Shinta SETIADEVI, Mustofa HILMI and Mita DAMAYANTI \\ Politeknik Negeri Banyuwangi, Banyuwangi, Jawa Timur, Indonesia \\ Email: akhusna@poliwangi.ac.id \\ Supporting Information
}

\begin{abstract}
The purpose of this study was to isolate and identify the morphological and biochemical properties of Acetobacter sp. Isolation is done by growing bacteria taken from pineapple (Ananas comosus L.) juice on Tryptic Soy Agar (TSA) media. Identification was carried out by biochemical tests namely catalase, motility, and oxygen use tests. The study was designed per descriptive analysis by evaluating and describing the collected data. The results of the morphological experiments showed that bacterial isolates isolated from pineapple had a milky white color, round shape, small size, smooth surface, flat elevation and gram-negative type. Biochemical tests showed positive reactions in the catalase test because of break-down capability of hydrogen peroxide by the enzyme catalase, while it was negative in the motility test because bacteria form a non-motile free sphere. Bacterial isolates showed a positive reaction in testing the use of oxygen because Acetobacter sp. need free oxygen for growth and activity. Isolation of Acetobacter sp. pineapple origin has macroscopic characteristics that are milky white color, round shape, smooth surface, and flat elevation. The results of the identification of Acetobacter sp. pineapple origin showed a positive reaction to the catalase test, which is a gram-negative bacteria and has a round shape. Future studies are recommended to conduct a polymer chain reaction test (PCR) to identify the strain of acetobacter sp.
\end{abstract}

Keywords: Acetobacter sp., Nata, Pineapple, Starter

\section{INTRODUCTION}

Nata is an extracellular polysaccharide layer (cellulose) consisting of a thin layer of gel or fine threads made by the bacterium Acetobacter sp. Low-calorie nata, 2.5\% fiber content, and $98 \%$ water content (Sako, 2012). Nata is robust, white and transparent, has a rubbery texture, and is floating on the surface of the liquid. The texture of the nata will tend to be difficult to bite or break easily (Budiarti, 2008). The production of nata can be influenced by the concentration of sugar used, fermentation time, nitrogen sources, and nutrient content in growth media.

Acetobacter sp. is a gram-negative bacteria that are included in the acetic acid bacteria. Acetobacter sp. can produce cellulose (nata) biofilms. The formation of cellulose (nata) is the result of the metabolism of Acetobacter sp., the process of which is controlled by the plasmid (Rezaee et al., 2005). The Acetobacter sp. group can be found in decaying fruits such as grapes, dates, coconuts, and pineapples and also some reveals of the production of vinegar of several types of substrates (Maal and Shafiee, 2009). The nutritional value contained in pineapple makes pineapple as a growth medium for Acetobacter sp. The nutritional value contained in pineapple makes pineapple as a growth medium for Acetobacter sp. the nutritional content needed by Acetobacter sp to live and thrive is sucrose, glucose, water, and fiber (Sutanto, 2012). Acetobacter sp. physically bacteria that are able to oxidize glucose into long chains or polymers called polysaccharides or cellulose in the form of white fibers, which form gradually from a thin layer at the beginning of fermentation to reach a thickness of about $12 \mathrm{~mm}$ at the end of fermentation, then referred to as nata which includes secondary metabolites. In addition to secondary metabolites, Acetobacter sp. also produce primary metabolite in the form of acetic acid, water and energy which is reused in at the same time its metabolism (Wu et al., 2004).

Pineapple is a fruit that is suitable for use as a food processing product (Majesty et al., 2014). According to Asif (2011) states that pineapple has a lot of content, one of which is the fiber that functions in the digestive process can reduce cholesterol in the blood and reduce the risk of diabetes to heart disease. The fiber content in pineapple is about 150 grams, equivalent to half of an orange. Pineapple $100 \mathrm{~g}$ contains $81.72 \%$ water; $20.87 \%$ crude fiber; $17.53 \%$ carbohydrate; $4.41 \%$ protein and $13.65 \%$ reducing sugar (Nurhayati et al., 2014). besides that in the study conducted Khusna et al. (2018) showed that pineapple fruit juice can be used as a starter in making nata.

\section{MATERIALS AND METHODS}

The procedure of researching Isolation and Identification of Acetobacter sp. the origin of pineapple as starter nata is done in several stages starting from the preparation of tools and ingredients, fermentation of pineapple juice and isolation of 
Acetobacter sp. from pineapple juice. The raw material applied in this study is ripe pineapple. The isolation and identification stages of Acetobacter sp. started by grinding 300 grams of pineapple, and then filtered. $100 \mathrm{ml}$ Pineapple juice was inoculated on TSA (Tryptic Soya Agar) media to obtain isolate Acetobacter sp. then incubated at $30^{\circ} \mathrm{C}$ for 24 hours, and after that, the isolation purification was carried out by taking a loop of the colony and then scraping it on the new TSA media. Purified isolates were identified by gram staining test, catalase test, motility test, oxygen use test.

\section{Gram Staining Test}

Gram staining is done using a glass slide cleaned with alcohol and then taken bacterial isolates with an ose needle aseptically and smeared on the glass object. Bacterial isolates were then dropped into violet crystals and left for 1 minute, then washed with running water and aerated to dry. Bacterial isolates are then dropped again iniodine solution and left for 1 minute, then washed with running water and air dry. Furthermore, bacterial isolates were added with $95 \%$ alcohol for 30 seconds, then was watered and aerated to dry. Bacterial isolates were then dropped in safranin for 30 seconds and washed with running water, dried with suction paper and air-dried, then observed using a microscope (Hatmanti, 2000). Gram-positive bacteria are marked with purple which indicates that they can bind violet crystalline colors, while gramnegative bacteria are characterized by pink which indicates that these bacteria are unable to bind violet crystal colors and are only colored by safranin (a counter dye) (Fitri and Yasmin, 2011).

\section{Catalase Test}

This test is done by dripping two drops of $\mathrm{H}_{2} \mathrm{O}_{2}$ on a clean slide glass. Bacterial isolates were taken using an ose needle, then transferred to the top of the slide and stirred A positive test is characterized by the formation of oxygen bubbles which indicate that the organism concerned produces the enzyme catalase which converts hydrogen peroxide into water and oxygen (Hatmanti, 2000).

\section{Motility Test}

This test is carried out using bacterial isolates inserted into the semi-solid TSA media in a test tube using a sterile puncture needle then incubated for 24 hours at $37^{\circ} \mathrm{C}$. A positive test is characterized by the growth of bacteria that spreads, then the bacteria moves (motile), and if the growth of bacteria does not spread in the form of only one line, then the bacteria do not move (non-motile) (Ismail et al., 2018).

\section{Oxygen Usage Test}

Oxygen Utilization Tests were carried out with isolates inoculated with a puncture inoculation technique on the semisolid YEPDA media. Then incubated for 48hours, and then observed the location of bacterial colonies. Bacteria are aerobic when the colonies are formed above and are anaerobic when the colonies are formed below.

\section{RESULT AND DISCUSSION}

\section{Isolation of Acetobacter sp.}

The results of isolation for the purification of Acetobacter sp. on pure culture TSA media grew evenly on each stroke. The results of the isolation of Acetobacter sp. presented in figure 1. After being successfully isolated, this isolate was confirmed to be morphological and biochemical. Morphological identification is carried out to determine the physical form of microorganisms, while biochemical identification is carried out to determine the chemical content in the body of microorganisms.

\section{Identification of Acetobacter sp.}

The results of the colony morphology and cell morphology are presented in Table 1.

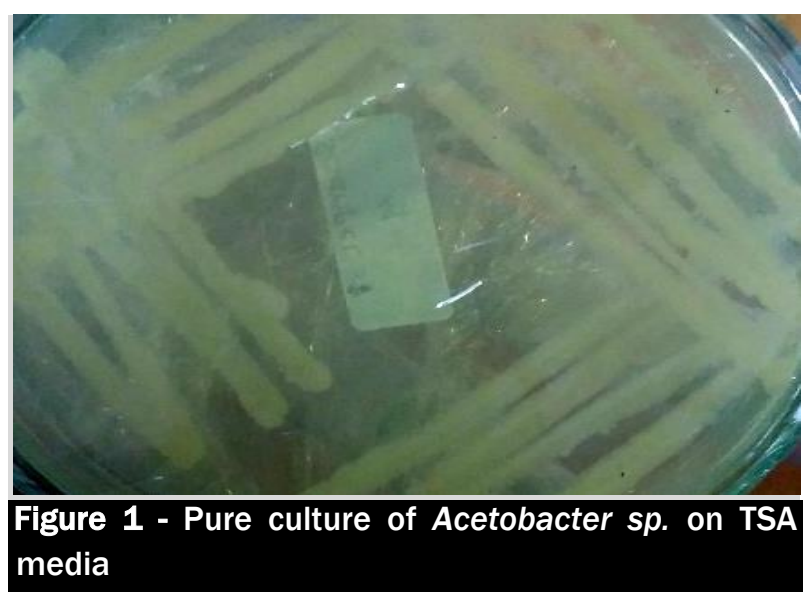

\begin{tabular}{|c|c|c|c|}
\hline \multicolumn{2}{|c|}{ Colony } & \multicolumn{2}{|c|}{ Cell } \\
\hline Character & Result & Character & Result \\
\hline Shape & Round & Shape & Round \\
\hline Color & Milky white & Size & Small \\
\hline Surface & $\begin{array}{c}\text { Smooth } \\
\text { shiny }\end{array}$ & $\begin{array}{c}\text { Gram } \\
\text { type }\end{array}$ & $\begin{array}{c}\text { Gram- } \\
\text { negative }\end{array}$ \\
\hline Elevation & Flat & - & - \\
\hline
\end{tabular}




\section{Morphology of the colony}

The results of macroscopic observations or observations of colony morphology showed that the isolates obtained had a round colony shape with a milky white color, smooth surface, and flat elevation. This is consistent with research conducted by Laras and Priyono (2012) that Acetobacter sp. has the characteristics of a rounded colony, white color, and flat elves. According to Azizah et al. (2012) that particular age and growth conditions influence the shape of a colony of a bacterium. The biotic and abiotic environment also influences variations in bacterial forms that occur, growth media and temperature (minimum and maximum) (Safrida et al., 2012).

\section{Cell Morphology}

Microscopic observations or cell morphological observations were carried out by gram staining. The results obtained showed that the isolate was round, small in size, and red, which indicated that the bacteria were included in gram contrary. Gram-positive bacteria are purple because the cell walls bind violet crystals more strongly while gram-negative bacteria contain more pleated, so pores quickly enlarge, and violet crystals dissolve easily when washing alcohol (Sariet al., 2013). The results of cell morphology are presented in figure 2. Gram-negative bacteria contain lipids and fat in a higher percentage than gram-positive bacteria (Ismail et al., 2018) besides gram-negative bacteria also have thinner peptidoglycan than gram-positive bacteria (Safrida et al., 2012). Gram-negative bacteria are more dangerous pathogens than Gram-positive bacteria because the outer membrane of the cell wall can protect bacteria from the host defense system. Lipopolysaccharide compounds in outer membrane gram-negative bacteria can be toxic or toxic (Dwiyanti, 2014)

\section{Biochemical Test Identification}

The parameters used for biochemical identification include catalase test, motility test, oxygen use test. The results of biochemical identification are presented in table 2.

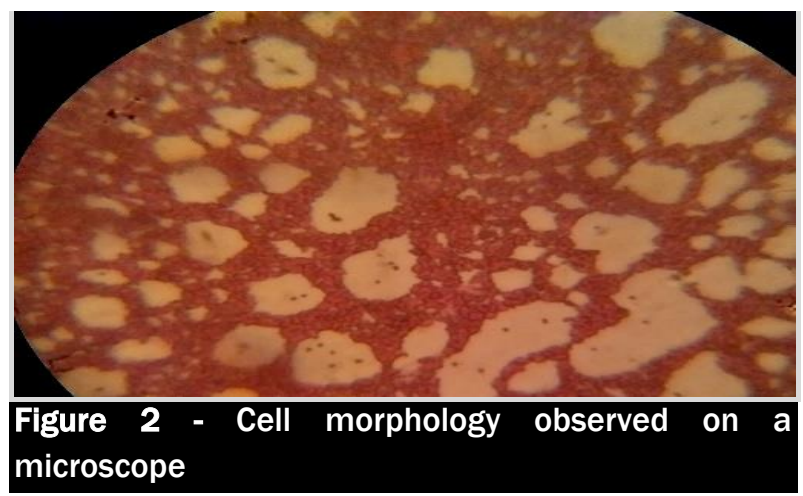

\begin{tabular}{ll} 
Table 2 - Biochemical Identification Results \\
$\begin{array}{ll}\text { Identification } \\
\text { Biochemistry }\end{array}$ \\
\hline $\begin{array}{l}\text { Catalase } \\
\text { Motility }\end{array}$ \\
\begin{tabular}{l} 
Use of $\mathrm{O}_{2}$ \\
\hline
\end{tabular}
\end{tabular}

\section{Catalase Test}

Catalase test is important to identification the specific characteristic of isolate target. Khairiah et al, (2013) said that some Acetobacter genus has catalase enzyme as their metabolism result. The results obtained in this catalase test bacteria form gas bubbles around the colony. The formation of gas bubbles in the colony indicates that the bacteria are positive. Bacteria produce catalase enzymes that can break down $\mathrm{H}_{2} \mathrm{O}_{2}$ into $\mathrm{H}_{2} \mathrm{O}$ and $\mathrm{O}_{2}$. Hydrogen peroxide is formed during aerobic metabolism, so aerobic microorganisms describe the material (Fitri andYasmin, 2011). The results of the catalase test are presented in figure 4.

The mechanism of the enzyme catalase breaks down $\mathrm{H}_{2} \mathrm{O}_{2}$, which is when doing a respiration; bacteria produce various kinds of components, one of which is $\mathrm{H}_{2} \mathrm{O}_{2}$. Bacteria that can break down $\mathrm{H}_{2} \mathrm{O}_{2}$ with the catalase enzyme then immediately form a defense system from the toxic $\mathrm{H}_{2} \mathrm{O}_{2}$ that it produces itself. Positive catalase bacteria will break down $\mathrm{H}_{2} \mathrm{O}_{2}$ into $\mathrm{H}_{2} \mathrm{O}$ and $\mathrm{O}_{2}$ were the parameters that indicate the presence of catalase activity in the presence of oxygen bubbles (Azizah et al., 2012).

\section{Motility Test}

The motility test aims to determine the characteristics of microorganisms through indole production from tryptophane. Microorganisms can be divided into 2 properties, namely motile and non-motile The results obtained in this study are non-motile bacteria. This is consistent with what Fatmadewi (2018) did if there was no movement around the needle puncture marks on the semi-solid TSA media showed negative or non-motile results, almost all spiral bacterial cells and some stem cell bacteria were motile, whereas bacteria that were a motile non-motile round shape. The results of the motilia test are presented in figure 5.

Research conducted using TSA semi-solid media did not have any movement in the sample; it showed that the bacteria was non-motile (not moving). Immovable or non-motile bacteria can be seen by not spreading the growth of bacteria or only growing in the puncture area on semi-solid TSA media (Mergypta et al., 2014). 

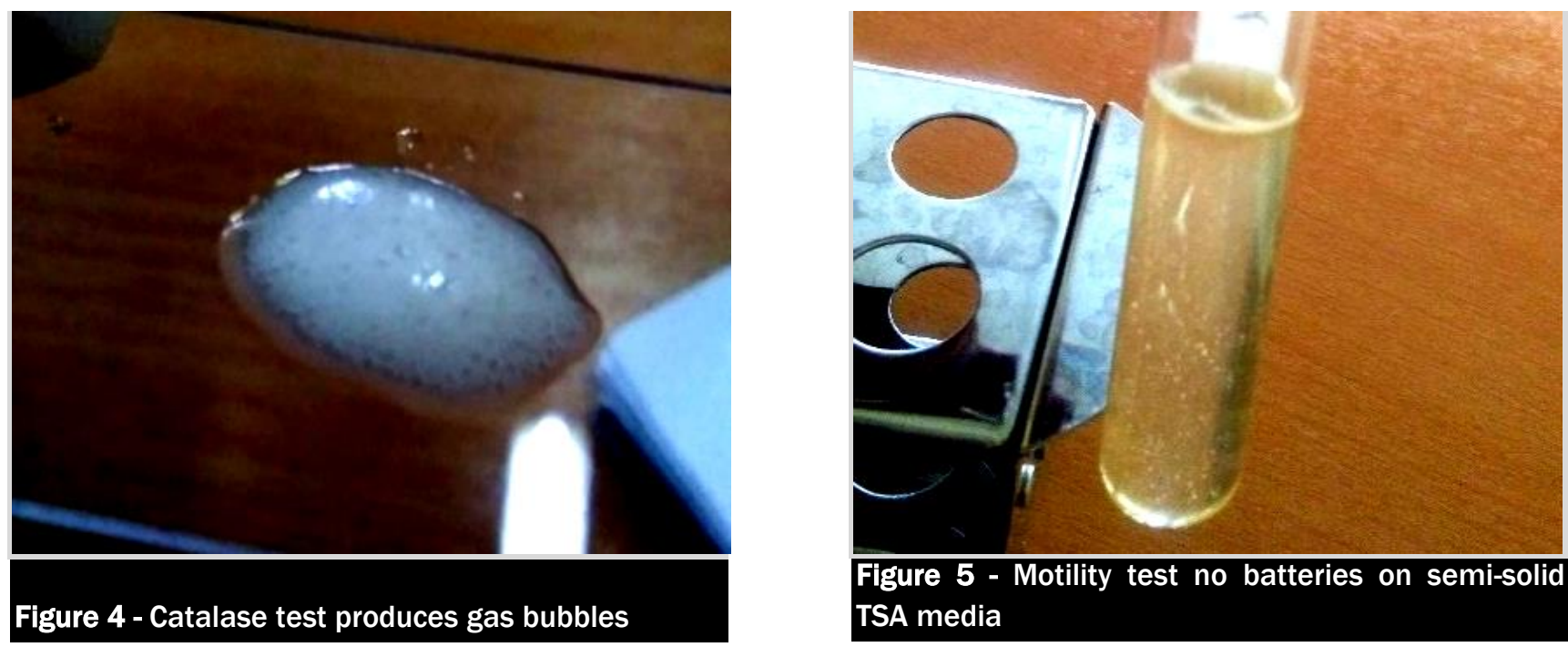

\section{Oxygen Usage Test}

The results obtained in this study the colonies formed above indicate that Acetobacter sp. aerobic. According to Yeni et al. (2011), Acetobacter sp. requires oxygen for growth and activity. Fitriadi (2019) added that aerobic bacteria would be on the upper surface because they would take free oxygen from the air. According to Simanjorang et al. (2012), Acetobacter sp. has obligate aerobic properties. Obligate aerobic nature is a trait of bacteria that requires oxygen to carry out aerobic cell respiration. Aerobic bacteria in oxygen utilization are bacteria that require much oxygen as the final acceptor in biological oxidation or aerobic respiration (Fifendy, 2017).

\section{CONCLUSION}

Isolation of Acetobacter sp. pineapple origin has macroscopic characteristics that are milky white color, round shape, smooth surface, and flat elevation. The results of the identification of Acetobacter sp. pineapple origin show a positive reaction to the catalase test, which is a gram-negative bacteria and has a round shape.

\section{DECLARATIONS}

\section{Corresponding Author}

Email: akhusna@poliwangi.ac.id

\section{Acknowledgments}

Thanks to the Politeknik Negeri Banyuwangi for funding given in the RIP Research scheme.

\section{Authors' Contribution}

AK and MD designed the study and drafted the manuscript, AUP and SS performed the practical part of the experiment. $\mathrm{MH}$ reviewed the manuscript. All the authors approved the final manuscript.

\section{Conflict of interests}

All the authors approved and agreed to publish the manuscript.

\section{REFERENCES}

Budiarti RS (2008). The influence of Acetobacter xylinum starter concentration on thickness and rendment of cellulose nata de soya. Biospecies, 1: 19 - 24. https://online-journal.unja.ac.id/biospecies/article/view/279

Sako S (2012). Study of nata de coco's damage levels are providing some swalayan in manado city. Cocos, 1(2): 525-1081. https://ejournal.unsrat.ac.id/index.php/cocos/article/view/525

Rezaee A, Solimani S and Forozandemogadam M (2005). Role of plasmid in production of Acetobacter xylinum biofilms. American Journal of Biochemichemistry and Biotechnology, 1(3): 121-124. http://docsdrive.com/pdfs/sciencepublications/ajbbsp/2005/121 124.pdf

Maal KB and Shafiee R (2009). Isolation and identification of an Acetobacter strain from Iranian white-red cherry with high acetic acid productivity as a potential strain for cherry vinegar production in food and agriculture biotechnology. World Academy of Science, Engineering and Technology, 54: 201-204. https://scialert.net/fulltextmobile/?doi=ajbkr.2010.53.59.

Sutanto A (2012). Pineapple liquid waste as nata de pina raw material. Makara Journal of Technology, 16(1): 63-67. http://journal.ui.ac.id/technology/journal/article/download/1286/205

Wu W, Gai B and Ji B (2004). Study on the isolation and identification of microbes of kombucha. Food Science, 25: 55-58. http://en.cnki.com.cn/Article_en/CJFDTotal-SPKX200404010.htm 
Majesty J, Argo BD and Nugroho WA (2014). Effect of adding sucrose and fermentation time to the levels of nata fiber from pineapple juice (nata de pina). Jurnal Keteknikan Pertanian Tropis dan Biosistem, 3(1): 80-85. http://jkptb.ub.ac.id/index.php/jkptb/article/download/256/216

Winastia B (2011). Analysis of amino acids in the bromelin enzyme in pineapple (Ananas Comusus) using a spectrophotometer. Skripsi. Semarang: Fakultas Teknik Universitas Diponegoro Semarang. https://core.ac.uk/download/pdf/11730977.pdf

Nurhayati N, Nelwida N and Berliana S (2014). Changes in the protein content and rough fiber of pineapple skin fermented with plain yogurt. Jurnal IImiah IImu-IImu Peternakan. 17(1): 31-38. https://www.online-journal.unja.ac.id/jiip/article/view/2044

Khusna A, Usfah A and Setiadevi S (2018). Utilization of cheese waste (whey ) to be nata de whey as a source of protein values economics in supporting nutritional community programs. Scholars Journal of Agriculture and Veterinary Sciences (SJAVS), 5(10): 553-556. D0I: https://dx.doi.org/10.21276/sjavs.2018.5.10.4.

Hatmanti A (2000). Identification of Bacillus spp. Oseana, 25(1): 31-41. http://oseanografi.lipi.go.id/dokumen/oseana xxv(1)31-41.pdf

Fitri $L$ and Yasmin Y (2011). Isolation and morphological observation of chitinolytic bacterial colonies. Jurnal Biologi Edukasi, 3(2): 20-25. http://jurnal.unsyiah.ac.id/JBE/article/view/465

Ismail YS, Yulvizar C and Mazhitov B (2018). Characterization of lactic acid bacteria from local cow's milk kefir. IOP Conference Series: Earth and Environmental Science. IOP Publishing: 12019. https://iopscience.iop.org/article/10.1088/1755$1315 / 130 / 1 / 012019 /$ pdf

Laras FA and Priyono S (2012). Effect of storage time of coconut water and sugar concentration on nata de coco characteristics and organoleptic. Jurnal Sains Mahasiswa Pertanian, 2(2): 2475. http://jurnal.untan.ac.id/index.php/ispp/article/view/2475

Khairiah E, Khotimah S and Mulyadi A (2013). Characterization and density of cellulose degrading bacteria on peat soils in the banjar trench village of Pontianak district. Protobiont, 2(2): 87-89. http://jurnal.untan.ac.id/index.php/iprb/article/view/2748/2721

Azizah N, Al-Barrii AN and Mulyani S (2012). Effect of fermentation time on alcohol content, pH, and gas production in the bioethanol fermentation process of whey with pineapple skin substitution. Jurnal Aplikasi Teknologi Pangan, 1(3): 72-77. http://jatp.ift.or.id/index.php/jatp/article/view/73/40

Sari ML, Abrar A and Merint M (2013). The isolated and characteristic lactic acid bacteria in broiler's intestine. Jurnal Agripet, 13(1): 4348. http://www.jurnal.unsyiah.ac.id/agripet/article/view/552

Safrida YD, Yulvizar C and Devira CN (2012). Isolation and characterization of potentially probiotic bacteria in mackerel (Rastrelliger sp.). DEPIK Jurnal IImu-IImu Perairan, Pesisir dan Perikanan, 1(3): 43-48. http://www.jurnal.unsyiah.ac.id/agripet/article/view/552/461

Dwiyanti W (2014). Effect of leaf extract (cosmos caudatus) on bacterial growth of Bacillus cereus by In Vitro. LenteraBio, 3(1): 1-5. https://jurnalmahasiswa.unesa.ac.id/index.php/lenterabio/article/view/7082/7672

Fatmadewi $L$ (2018). Isolation of lactic acid bacteria from cow intestine (Bos taurus) and the ability to inhibit the growth of Eschericia coli and Shigella sp. Universitas Medan Area. http://repository.uma.ac.id:8081/bitstream/123456789/9404/1/Lulu\%20Fatmadewi\%20\%20fulltext.pdf

Mergypta D, Budiharjo A and Kusdiyantini E (2014). Isolation, characterization of lactic acid bacteria, and proximate analysis of fermented anchovy fermented food (Stolephorus sp.). Jurnal Akademika Biologi, 3(2): 11-19. https://ejournal3.undip.ac.id/index.php/biologi/article/viewFile/19440/18439

Fitriadi A (2019). Provision of Some Organic Fertilizers on the Physical and Chemical Properties of Soil Cocoa (Theobroma cacao L.). GrahaTani, 5(1): 711-719. http://jurnal.ugn.ac.id/index.php/GrahaTani/article/download/197/172

Yeni LF, Hidayat A and Marlina R (2011). Isolation and fermentation activity of acetic acid bacteria in palm sap (Nypa fruticans). Jurnal Pendidikan Matematika dan IPA. 2(1): 1-10. http://jurnal.untan.ac.id/index.php/pmp/article/download/2173/2114

Simanjorang E, Kurniawati $N$ and Hasan Z (2012). Effect of the use of the enzyme papain with different concentrations on the chemical characteristics of ketchup. Jurnal Perikanan Kelautan, 3(4): 209-220. http://jurnal.unpad.ac.id/jpk/article/view/2564/2321

Fifendy M (2017). Mikrobiologi. Kencana. https://books.google.co.id/books?hl=en\&lr=\&id=AVNDwAAQBAJ\&oi=fnd\&pg=PA1\&dq=Fifendy+M+(2017).+Mikrobiologi.+Kencana.\&ots=qGtOpIM1Fa\&sig=L83Mg38r8jtNh_8Ke9szyA w-CvE\&redir_esc=y\#v=onepage\&q=Fifendy\%20M\%20(2017).\%20Mikrobiologi.\%20Kencana.\&f=false 